\title{
Study of microfinance farmer to make decision for formal and informal credit
}

\author{
Andrean Eka Hardana*', Destyana Ellingga Pratiwi, Dian Islami Prasetyaningrum, Sugeng \\ Riyanto, and Mangku Purnomo
}

Faculty of Agriculture, University of Brawijaya, Malang, Indonesia

\begin{abstract}
The study aimed to identify the microfinance implementation by horticultural farmers and analyze the factors influencing the horticultural farmers' decision to choose the financial institutions. The research location was carried out in two areas, namely (a) Wonomulyo Village, Poncokusumo Subdistrict, Malang Regency, dan (b) Pacet Village, Pacet Subdistrict, Mojokerto Regency. The sample determination was carried out using the Slovin formula using the proportional stratified sampling method. The total sample was 160 farmers. Descriptive and logistic regression analysis (logit) were used to answer the objective of the study. Formal institutions assigne ${ }^{1} \mathrm{~d}$ to channel the funds include government banks and private banks. Informal institutions that carried out micro-credit funds were the private sector or institutions from the farmers themselves. The majority of farmers knew that the rate level of formal financing sources was lower, but the administrative procedures were considered problematic. The regression's results showed that the factors influenced the decisions of Horticulture farmers to take micro-finance access, including education, length of business, interest rate, and loan amount.
\end{abstract}

\section{Introduction}

Capital is one of the essential production factors in agriculture. However, in their business operations, not all farmers have sufficient capital. Credit has become the community's choice as a way out to meet increasing needs, including for the agricultural sector [1]. Insufficient income has led to a rising trend in lending, both formal (such as state and private banks) and informal financial institutions (such as farmer groups, cooperatives, other farmers, and traders) [2].

Most business financing in the agricultural sector is based on interest calculations [3]. The banking sector generally shows a lack of interest in financing the agricultural industry that is considered high risk, either due to natural disturbances such as floods and droughts, pests, and plant diseases, as well as fluctuations in output prices. The government has tried to help ease the capital burden on farmers by establishing various financing schemes that are easily accessible to small farmers. This policy is expected to have a positive impact on the development of smallholder farming in Indonesia.

\footnotetext{
* Corresponding author: andrean@ub.ac.id
} 
The fundamental problem for the development of agricultural businesses is the poor access of farmers to both formal and informal sources of capital. The small scale of the business causes the poor access to capital cannot carry out capital accumulation. So, the use of informal financing is also often an alternative for farmers to finance their farming activities, even though the payment mechanism narrows the ability of farmers to accumulate capital [4].

East Java is one of the leading agricultural centers in Indonesia. Thirty-six percent of the population works in the agricultural sector [5]. The magnitude of this potential makes the behavior of farmers in this area quite representative of the behavior of farmers in Indonesia in general. Meanwhile, the horticultural crop sub-sector, especially vegetables, is the subsector with the second-highest sectoral contribution growth (to Indonesia's GDP) after plantation crops [6]. Therefore, this research was focused on horticultural farmers in East Java.

A financing program is considered adequate if it supports farmers to accumulate capital and improve their socio-economic conditions. The key to the success of microfinance in the long term is to seek the accumulation of returns [7]. Therefore, this research focused more on farmers' decisions in making credit decisions, patterns of credit use, and their effectiveness in improving farmers' welfare.

\section{Methodology}

The data collection carried out from June to September 2018 in two locations: (a) Wonomulyo Village, Poncokusumo Subdistrict, Malang Regency, and (b) Pacet Village, Pacet Subdistrict, Mojokerto Regency. The two locations were the vegetable-producing centers in East Java with the most financial institutions. The number of household samples of horticulture farmers in these two areas was 160, with the proportion of 52 farmers who were not credit users, 43 farmers who were formal credit users, and 65 farmers who were non-formal credit users.

Table 1. Identification of variables in logit model

\begin{tabular}{|c|c|c|}
\hline \multicolumn{1}{|c|}{ Dependent variables } & Independent Variables \\
\hline $\mathrm{Y}=1$, if the farmer uses formal credit & $\mathrm{X}_{1}=$ Age \\
$\mathrm{Y}=0$, if the farmer uses informal credit & $\mathrm{X}_{2}=$ Education \\
$\mathrm{X}_{3}=$ Family Members \\
$\mathrm{X}_{4}=$ Length of Business \\
$\mathrm{X}_{5}=$ Loan Amount \\
$\mathrm{X}_{6}=$ Interest Rate \\
$\mathrm{X}_{7}=$ Land Area \\
$\mathrm{X}_{8}=$ Land Status \\
$\mathrm{X}_{9}=$ Income \\
\hline
\end{tabular}

Source: Primary Data Processed (2018)

Descriptive statistical analysis is an analysis that was utilized to describe the data through sample or population data as they were, without conducting analysis and making conclusions that applied in general. This study used a regression analysis of the logit model, which needed 
to answer what factors influence farmers' decisions to use credit from formal financial institutions for their farming capital.

The independent variables in the model measured based on the total score from the measurement of each indicator they have. Therefore,

$$
\begin{gathered}
\operatorname{Prob}(Y=1 \mid x)=P \\
\operatorname{Prob}(Y=0 \mid x)=1-P
\end{gathered}
$$

Since the probability $(P)$ must lie between 0 and 1 , there was a limitation: $0 \leq \mathrm{E}[\mathrm{y} \mid \mathrm{x}] \leq 1$. The interpretation of the logit model showed the probability of farmers using fintech that shown by the equation:

$$
\begin{gathered}
\operatorname{Prob}(Y=1 \mid x)=P=\frac{e^{z}}{1+e^{z}} \\
\text { with } Z=\beta_{0}+\beta_{1} X_{1}+\beta_{2} X_{2}+\beta_{3} X_{2}+\beta_{4} X_{4}+\cdots+\beta_{10} X_{10}
\end{gathered}
$$

If $\mathrm{P}$ was the probability of farmers using fintech, then the probability of farmers not using fintech was:

therefore,

$$
\operatorname{Prob}(Y=0 \mid x)=1-P=\frac{1}{1-e^{z}}
$$

$$
\frac{P}{1-P}=\frac{1+e^{z}}{1+e^{-z}}=e^{z}
$$

$\frac{P}{1-P}$ (Odds ratio), namely, comparing the probability of farmers using fintech to the probability of farmers not using fintech. Thus, the logit model in this study was:

$$
L i=\ln \left[\frac{P}{1-P}\right]=y=\beta_{0}+\beta_{1} X_{1}+\beta_{2} X_{2}+\beta_{3} X_{2}+\beta_{4} X_{4}+\cdots+\beta_{10} X_{10}
$$

In which:

$1-10=$ Regression coefficient

$\mathrm{P}=$ Probability of farmers using one of the farming credits

$\mathrm{P}-1=$ probability of farmers not taking advantage of one of the farming credits

\section{Results and discussions}

\subsection{Implementation of microfinance for agriculture by horticultural farmers in East Java}

There were two types of credit markets, or financing markets, in the two locations studied: the formal and informal financing markets. Formal financing (especially for non-program activities) operated in rural areas, which followed the market mechanism in the submission and distribution mechanism. The rules of eligibility were applied formally, such as the interest rate charged was the commercial interest rate and was served by a formal institution. Informal institutions that played a role include traders of agricultural inputs, agricultural products, and traders who functioned both, namely input and output traders. Meanwhile, according to custom or in terms of behavior and attitude patterns of the farming community, having debt was not a disgrace. Even going into debt to meet farming financing needs was a common thing to do.

The rules for formal financing schemes for agricultural businesses were rigid, making it difficult for farmers and rural communities to access the financing sources. The financing 
policies that were expected to support the development of agricultural businesses were intended to be very weak and ignored this sector. The majority of farmers generally knew that the interest rate for formal financing sources was indeed lower. Still, administrative procedures were considered problematic, the time for disbursement was long/slow, and the amount of credit received was sometimes not as expected, both in terms of amount and time of realization.

The loan procedure at these informal institutions was simple and easy, the availability of funds was relatively limited and the interest rate was higher than formal financing institutions. Farmers think that this institution had simple administrative procedures, quick/on-time loan disbursement as needed but with higher interest rates. However, farmers' assessment of interest rates was very relative. Some of them think that their willingness to provide loans was more interpreted as "assistance" or "help" to them in overcoming problems with farming financing. So that the higher interest rate that must be paid was considered as remuneration and not burdensome.

\subsection{Analysis of factors considered by horticultural farmers in East Java in choosing financial institutions}

A partial test conducted to test the significance of the coefficients partially using the Wald test statistic. The Wald test was carried out by comparing the Wald value in the results of the logistic analysis with the chi-square table value at degrees of freedom 1 (df 1) with a significance level of $10 \%(\alpha=0.1)$ which was 2.71 . If the Wald value $>$ the chi-square table value, this variable had a significant partial effect on selecting formal and informal types of credit. If the Wald value $<$ chi-square table value, this variable did not have a significant partial impact on the selection of formal and informal types of credit.

Table 2. The Result of Partial Test Analysis

\begin{tabular}{|c|c|c|c|c|c|c|c|}
\hline \multicolumn{2}{|c|}{} & B & S.E. & Wald & df & Sig. & Exp(B) \\
\hline \multirow{5}{*}{} & Age* & .131 & .056 & 5.374 & 1 & .020 & 1.140 \\
\cline { 2 - 8 } & Education* & .239 & .117 & 4.166 & 1 & .041 & 1.271 \\
\cline { 2 - 8 } & Family Members & -.430 & .262 & 2.684 & 1 & .101 & .650 \\
\cline { 2 - 8 } & $\begin{array}{c}\text { Length of } \\
\text { Business }\end{array}$ & -.124 & .056 & 4.945 & 1 & .026 & .883 \\
\cline { 2 - 8 } & Loan Amount* & .000 & .000 & 15.145 & 1 & .000 & 1.000 \\
\cline { 2 - 8 } & Interest Rate* & .030 & .016 & 3.536 & 1 & .060 & 1.030 \\
\cline { 2 - 8 } & Land Area & -.048 & .441 & .012 & 1 & .914 & .954 \\
\cline { 2 - 8 } & Land Status & -.358 & .824 & .189 & 1 & .664 & .699 \\
\cline { 2 - 8 } & Income & .000 & .000 & .359 & 1 & .549 & 1.000 \\
\cline { 2 - 8 } & Constant & -5.676 & 2.504 & 5.139 & 1 & .023 & .003 \\
\hline
\end{tabular}

Source: Primary Data Processed (2018)

Based on the table 3, the model for selecting the formal and informal credit types as follows:

$$
\begin{aligned}
\mathrm{Y}= & \ln \left(\frac{P_{i}}{1-P_{i}}\right)=-5,676+0,131 X_{1}+0,239 X_{2}+-0,430 X_{3}+-0,142 X_{4}+0,000 X_{5}+0,030 X_{6}+ \\
& -0,048 X_{7}+-0,358 X_{8}+0,000 X_{9}+\varepsilon
\end{aligned}
$$


In which:

$Y=$ Credit Types Selection $(1=$ Formal; $0=$ Informal $)$

$x_{1}=$ Age

$x_{2}=$ Education

$x_{3}=$ Family Members

$x_{4}=$ Length of Business

$x_{5}=$ Loan Amount

$x_{6}=$ Interest Rate

$x_{7}=$ Land Area

$x_{8}=$ Land Status

$x_{9}=$ Income

$\varepsilon \quad=$ Random Variable

\subsubsection{Age}

Age affected the selection of formal and informal credit types because the statistical value of the Wald test was greater than the value of the chi-square table in df $1(5.374>2.71)$ with a significance level of $10 \%(0.1)$. Age had a significant partial effect on the selection of formal and informal credit. The age variable had an odds ratio of 1.140, which indicated that the opportunity to choose the type of formal credit influenced by age was 1.140 times greater than selecting the type of informal credit.

Age had a positive coefficient (0.131), and then the age variable had a positive relationship to farmers' decisions in choosing the formal and informal credit. The higher the farmer's age, the higher the desire to select the formal credit. The older farmers tended to have many considerations in choosing types of credit to avoid risk because they have qualified farming experience [8]. It was not in line with research by [2], which suggested that the age of farmers thought to affect the total loan. The higher the age of the farmer, the lower the farmer's loan rate. The higher the age of the debtor, the smaller the productive age of the loan, so that financial institutions would reduce the amount of loans to farmers to reduce the risk level of credit repayment.

\subsubsection{Education}

Education affected farmers' decisions in choosing the formal and informal credit types because the statistical value of the Wald test was greater than the value of the chi-square table in df $1(4.166>2.71)$ with a significance level of $10 \%(0.1)$. Education had a significant partial effect on the choice of formal and informal credit types. The selection of financial institutions based on the educational level showed that the horticultural farmers had a 1,271 times greater chance of choosing formal credit institutions than non-formal credit institutions. Education brought a positive coefficient (0.239), and then the education variable had a positive relationship to farmers' decisions in choosing the type of formal and informal credit. The higher the level of education of farmers, the ability of farmers to select the formal credit would increase. The education variable in Nguyen's [9] study had a positive coefficient, where educated farmers gained a better understanding of banking procedures and rules to obtain and use formal banking financial products and services. Therefore, people with higher education had a heightened awareness of the credit facilities available in their area and searched for more information. 


\subsubsection{Family members}

The number of family members did not affect farmers' decisions in choosing the formal and informal credit types because the statistical value of the Wald test was smaller than the value of the chi-square table in df $1(2.684<2.71)$ with a significance level of $10 \%(0.1)$. It portrayed that the number of members did not have a significant partial effect on the choice of formal and informal credit. It was contrary to [1], which stated that the number of members would influence farmers' decisions in choosing formal and informal credit. Farmers with a large number of members could use more capital for labor and other agricultural inputs. It would increase the demand for credit to formal and informal credit institutions. The logistic regression test results displayed no relationship between the number of family members and the farmer's decision to choose the formal and informal credit due to many factors that influenced farmers in influencing credit and interconnected with each other. Based on the field results, the decision of farmers to use credit based on the capital ownership of the farmer's household.

\subsubsection{Length of business}

The length of business affected the farmers' decisions in choosing the formal and informal credit types because the statistical value of the Wald test was greater than the value of the chi-square table in df $1(4.945>2.71)$ with a significance level of $10 \%(0.1)$. The length of business brought a significant partial effect on the choice of formal and informal credit. The selection of financial institutions based on the length of business showed that horticultural farmers had a 0.883 times greater chance of choosing formal credit institutions than nonformal credit institutions. Length of business has a negative coefficient $(-0.124)$, then the variable length of business had a negative relationship to farmers' decisions in choosing the formal and informal credit. The longer they ran the business, the selection of formal credit types will decrease. The longer the farming business, the farmers' ability to choose formal credit would decrease. It was because farmers who had been running a farming business for a long time were considered more capable of managing a farming business. Farmers' finances and capital were also more stable, so access to credit was no longer needed [10].

\subsubsection{Loan amount}

Loan amount affected farmers' decisions in choosing the type of credit because the statistical value of the Wald test was greater than the value of the chi-square table in df 1 (15.145 > $2.71)$ with a significance level of $10 \%(0.1)$. It showed that the loan amount had a significant partial effect on the decision to choose formal and informal credit. The selection of financial institutions based on the amount of the loan showed that horticultural farmers have a 1,000 times greater chance of choosing formal credit institutions than non-formal credit institutions.

The loan amount had a positive coefficient $(0.000)$, so the loan size variable had a positive relationship to farmers' decisions in choosing formal and informal credit. The bigger the loan, the higher the decision of farmers to take formal credit. Informal financial institutions could not provide the increased loan amount. So, farmers tend to choose formal financial institutions for large amounts of credit. It was in line with Rahayu's [11] research, which stated that formal financial institutions could meet the needs of farmers who needed large funds or credit compared to non-formal financial institutions. 


\subsubsection{Interest rate}

Interest affected the decision of farmers in choosing the formal and informal credit because the statistical value of the Wald test was greater than the value of the chi-square table in $\mathrm{df} 1$ $(3.536>2.71)$ with a significance level of $10 \%(0.1)$. It explained that interest had a significant partial effect on choosing formal and informal credit. The selection of financial institutions based on the interest showed that the horticultural farmers had a 1,000 times greater chance of choosing formal credit institutions than non-formal credit institutions. Interest brought a positive coefficient $(0.030)$, and then the interest variable had a positive relationship to farmers' decisions in determining the formal and informal credit. In line with Mohieldin and Write's [12] statement, that formal credit was mostly known for financing the production and the interest rate was relatively low due to the subsidy from the government. Interest rates on informal credit were higher and characterized by irregularities in many aspects. Informal financial institutions worked speculatively, and there was no government regulation. The government regulated the formal credit activities, particularly the rules between depositors and lenders. In contrast, informal credits provided loans from individuals, professional loan sharks, traders, commission agents, landlords, friends, and family for the informal credit market.

\subsubsection{Land area}

The land area did not affect farmers' decisions in choosing the type of formal and informal credit because the statistical value of the Wald test was smaller than the chi-square table value in df $1(0.012<2.71)$ with a significance level of $10 \%(0.1)$. It showed that land area did not significantly affect the selection of formal and informal credit. It was not in line with the results of research by [4], which suggested that with every increase in the area of business land, the more opportunities for farmers to access credit, due to the expectation of increased operating costs for farming, including input costs, labor, and maintenance costs.

\subsubsection{Land status}

Land status did not affect farmers' decisions in choosing formal and informal credit types because the statistical value of the Wald test was smaller than the chi-square table value in df $1(0.189<2.71)$ with a significance level of $10 \%(0.1)$. It showed that land status did not significantly affect the selection of formal and informal credit. The results of this study were not in line with Afandi's research [13] which stated that land ownership status could be used as collateral (collateral) that can be given by farmers when access credit. Based on the study results, land status does not affect farmers in choosing formal and informal credit because, in the research area, most of the cultivated land was not owned by itself (rent).

\subsubsection{Income}

Income does not affect farmers' decisions in choosing the type of formal and informal credit because the statistical value of the Wald test is smaller than the value of the chi-square table in df $1(0.359<2.71)$ with a significance level of $10 \%(0.1)$. It displayed that income did not have a significant partial effect on the choice of formal and informal credit types. Income in each season is always fluctuating, depending on market conditions. Sometimes the prices are high, and sometimes it can be low, so income could not be used as a benchmark in choosing the types of formal and informal credit [13]. 


\section{Conclusion}

Loan procedures at these informal institutions are simple and easy, the availability of funds is relatively limited, and the interest rate is higher than that of formal financing institutions. In contrast, the rules of formal financing schemes for agricultural businesses are rigid, making it difficult for farmers and rural communities to access these financing sources. The factors that influence the decisions of horticultural farmers in East Java in accessing credit include education, length of business, land area, and income. At the same time, the factors considered by horticultural farmers in East Java in choosing financial institutions include age, education, length of business, amount of loan, and interest rate.

Need more explanation about the factor influence the farmers decision in choose the type of credit system?

Acknowledgement. The authors would like to express their gratitude to the Research and Community Service Institute of Brawijaya University (LPPM-UB) for the support to conduct research on microfinance in the Beginner Research Grant (HPP).

\section{References}

1. A. Lemessa, Assifaw, A. Gemechu. International Journal of African and Asian Studies, 25 (2016)

2. F.A. Ajagbe, B.A. Oyelere, J.O. Ajetomobi. American Journal of Social and Management Sciences, 3, 1 (2012)

3. Ashari, Saptana. 2005. Forum Penelitian Agroekonomi. 23, 2 (2005)

4. Ibrahim, A. Hassan, S. Bauer. Global Advanced Research Journal of Agricultural Science, 2, 3 (2013)

5. Kominfo Jatim. Tahun 2016 PDRB Jatim Capai Rp 1.855 Triliun. http://kominfo.jatimprov.go.id/read/umum/tahun-2016-pdrb-jatim-capai-rp-1-855triliun. [20/03/18] (2016)

6. Pusdatin. Analisis PDB Sektor Pertanian Tahun 2015. (Jakarta: Kementerian Pertanian, 2015)

7. Ahlin, Jiang. 2008. Can micro-credit bring development? Journal of Development Economics, 86, 1 (2008)

8. Saqib, E. Shahab, K.M. John, Kuwornu, S. Panezia, U. Ali. Kasetsart Journal of Social Sciences. (2017)

9. H. Nguyen, H. Brian, Kleiner. Leadership \& Organization Development Journal, 24, $8(2003)$

10. D.R. Wati. Jurnal Agribisnis, 9, 2 (2015)

11. L. Rahayu. Jurnal Agraris, 1, 1 (2015)

12. M. Mohieldin, P. Wright. Economic Development and Cultural Change, 48 (2000)

13. P. Afandi. Jurnal Among Makarti, 3, 5 (2010) 